\title{
The Technological Priesthood
}

Science and religion traditionally do not mix particularly well. This should not be too surprising since there is an obvious dichotomy between the scientific reliance upon "provability" and the religious exercise of faith; but there are some striking similarities between science and religion, too. Just as the various religions have certain problems among themselves, different scientific disciplines sometimes have a hard time understanding each other's viewpoints on shared subject matter.

I consider myself lucky to have a close family connection to three of the major branches of Judeo-Christian monotheism, but it does not matter which religion one subscribes to if one does not really practice it. Lapsed adherents of religious faiths sometimes have a lot in common with lapsed MRS members-they periodically reclaim their membership through occasional attendance, and the extent of "lapsedness" can be measured by the occasions that call for religious observance. Some people go to church every Sunday, some go at Christmas and Easter, and some go only for weddings, baptisms, and funerals. Within one part of my family, the least religiously observant members are sometimes accused of only seeing the priest at their own birth and death (i.e., when they have no control over it).

Although science and religion are often estranged from each other, many of the products of modern technology are like lapsed acolytes in the way that they relate to materials scientists. The materials professional is there at the birth of the product, since someone has to decide what to make it from. The materials professional is also frequently there at the "death," whether it occurs via catastrophic failure or by obsolescence, because someone has to determine why it failed or wore out and how to design the next generation to make it immune to the same problems. Note that it is always the material that wears out, never the part. (Perhaps I should be even more cynical and suggest that the real reasons for investigating the demise of a product are either to assign blame or to guarantee that failure will henceforth occur just as soon as the warranty expires, but that is too easy.) In any event, the materials engineer is only reliably present at the two extreme ends of the product life-cycle, and to this extent he or she parallels the role of the priesteven if, unlike the materials scientist, the priest may not ever be a woman. Of course, physicians are also routinely present at births and deaths, but it is much more fun to compare our work to a religion than to the practice of medicine, though there are elements of the mysterious in both realms.

\section{If materials scientists are like spiritual leaders, then how much like a religion is materials science?}

If materials scientists are like spiritual leaders, then how much like a religion is materials science? Well, it has certain articles of faith, most of which relate to the Second Law of Thermodynamics. (The Second Law, of course, has been raised to the status of a creed by Einstein's proclamation that it is the only scientific law that will never be disproven.) Our work involves certain mysterious symbols that are inscrutable to the uninitiated-like stereographic projections, phase diagrams, and Thompson tetrahedra, all of which look, at first, as if they should be operated by some kind of wizard, whitebearded, robed, and muttering strange incantations. And, like many religions, materials science has many uninitiated and variously passionate followers. Every child who ever made a downhill racer knows that wood is the best choice for the structural components. Many of the same children also know that although window glass is usefully transparent, it is tragically brittle when subjected to projectile assaults, so they have a good grasp of materials properties, at least. This is a religion like many others then, where chil- dren learn the basics, but often grow weary of it (or "too cool" for it) in their teenage years, and only the most devout and persistent make it to the priesthood.

Of course, many lay adults cling ferociously (and selectively) to one or another part of the system of beliefs, as reflected in the snippet I overheard recently in my local hardware megastore: "Well, I use PVC in preference to metal everywhere." (Was he really trying to say, "Thou shalt not steel?")

Materials science has its own places of worship, in universities and national laboratories, although they are perhaps more akin to monasteries than to churches (and hopefully they lack the accompanying vows of poverty). Within many of these places of worship there are special inner sanctuaries where only the anointed few may work and all others must show due deference, speaking only in hushed tones that will not bring harm to the iconic and mysterious electron microscopes. Special vestments are required in certain places of worship, such as foundries or clean rooms. And, of course, there are festival gatherings of the faithful in great celebrations that involve large-scale ritual eating and drinking (observed annually in Boston and San Francisco).

The signature characteristic of any well-established religion, of course, is the existence of independent sects, each one of whose members are sure that they are the bearers of the only real truth. Perhaps such things exist within the ranks of materials scientists.

All in all, I think a visitor from another universe might easily confuse our daily work with the practice of a religion, and if they do, then we materials scientists are surely the high priests of the technological world, attending the births and deaths of each generation of technology. Like priests, we may wish to have greater impact throughout the product lifetime, but ultimately our job security truly lies in the ongoing certainties of technological birth and death. Go forth in peace and (if you can manage it) harmony.

Alex KING 